\title{
The Creation And Implementation Of A Student Civility Code
}

John J. Lucas, (Email: jlucas@calumet.purdue.edu), Purdue University, Calumet Gloria Rolden-Scheib, Purdue University, Calumet

\begin{abstract}
This paper examines the design and implementation of a student civility code at a regional campus of a Big Ten University. The paper also provides some guidelines to address student incivility in both the classroom and service offices throughout a higher education institution. The communication of such a student code to promote civility was critical and has also been discussed.
\end{abstract}

\section{BACKGROUND}

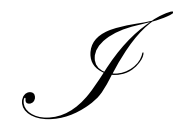

n the Spring 2005, a special task force on student civility was established at Purdue University Calumet. The task force on student civility was created to address a growing concern among faculty and staff regarding student incivility in both the classroom and service offices throughout the university. Some of the primary objectives of the task force were to: create a student civility code to be implemented across the campus, develop faculty and staff guidelines on how to maintain civility in classes and throughout the campus, educate the university community on the civility code and dealing with disruptive behavior, and develop a plan to communicate the student civility code throughout the campus. The membership of the student civility task force consisted of both university administration and faculty. The fifteen members of the committee were selected because of their knowledge and experience that would play a crucial role in the development and implementation of the student civility code.

At the first scheduled meeting, members of the student civility task force discussed their primary purpose, function, and goals. Team members also agreed that they needed to identify peer universities that would be benchmarked, based on their methods of facilitating student civility or civility plans and codes. Each committee member was assigned a peer university or college of his or her choice to determine the school's student civility plan. Additionally, the task force also decided to review current literature on how to understand and manage student incivility within the university.

Over the next few meetings, the committee focused on two specific tasks that the group members needed to accomplish in order to attain its goal. First, the committee developed a timeline so that their findings and recommendations could be presented to the University Faculty Senate for approval prior to the end semester. Second, group members needed to report and discuss their findings from the various benchmarked universities and colleges. With the accomplishment of these two tasks, the committee was then ready to focus energies on creating a Student Civility code.

\section{LITERATURE REVIEW}

Many articles and books have been written regarding student incivility and the appropriate methods to address inappropriate behavior by students. In "Campus Life: In Search of Community," the American Council on Education and the Carnegie Foundation for the Advancement of Teaching reported that the quality of campus life across the nation had deteriorated in recent years and also that the result was an "alarming lack of civility and consideration" toward other students as well as faculty members. The report also recommended the creation of a "campus compact" outlining an array of principles, values, and expectations that fostered a community of mutual respect for others. 
James Kauffman and Harold Burbach (1998) suggested that creating a climate of civility in the classroom was the most effective and enduring action that educators could undertake. They recommended that teachers could attain civility in their classroom by: engaging in self-analysis, imagining a climate of civility, building a repertoire of initiatives and responses, and making a short, as well as a long, term commitment to civility. Virginia Gonzalez and Estela Lopez (2000) identified six major categories of student incivility: disengagement, disinterest, disrespect, disruption, defiance, and disturbance. They also advocated three primary steps to offset uncivil behavior in the classroom: creation of behavioral standards, enforcement of standards of behavior, and examination of instructional methodologies to mitigate uncivil behavior.

Patrick J. Morrisette (2001) defined incivility as the intentional behavior of students to disrupt and interfere with the teaching and learning process of others. He also indicated that this inappropriate behavior hindered the learning process for other students and, therefore, was a blatant violation of their rights. Furthermore, student incivility may also contribute to faculty stress, discontent, and even burnout. He suggested ten practical strategies to reduce student incivility: (1) using effective communication skills; (2) spelling out academic and behavioral expectations in the syllabus; (3) arranging mid-term teaching feedback; (4) arranging peer observations and reviews; (5) establishing a collaborative learning environment; (6) setting a good example; (7) reframing potential conflicts; (8) re-engaging students; (9) establishing student grievance process; (10) using back-to-the-basics approach.

\section{CREATION OF A STUDENT CIVILITY CODE}

The committee was aware of the importance of a clear and well- developed Student Civility code. This code would be a central component of the procedures and guidelines for faculty, staff; and students throughout the university. All hard copies and on-line brochures would reflect and reference the Student Civility code.

At the next meetings, the task force members participated in brainstorming sessions to create a Student Civility code. Brainstorming was a technique that encourages group members to generate as many ideas as possible in an atmosphere that was nonjudgmental and non-critical (Verchio, 2002). In other words, brainstorming was a technique that encouraged team members to exchange new ideas or concepts without a feeling of uneasiness that has commonly been caused in face-to-face groups. For brainstorming to be successful, a series of basic rules must be adhered to: no idea is too ridiculous, no ideas can be criticized, and each idea belongs to the group not to the individual who suggested it (Ivancevich and Matteson, 2002). At the end of each brainstorming session, team members were encouraged to e-mail any additional comments or suggestions to the chairpersons of the task force.

After several elaborate discussions, the committee finally agreed to the following code:

\section{STUDENT CIVILITY CODE}

Purdue University Calumet places a priority on student learning. We value the inherent worth and dignity of every person, thereby fostering a community of mutual respect. We believe that in order to achieve these ideas, all Purdue University Calumet students are expected, while in the role as student or representative of the university, to exhibit, and practice civil behaviors that exemplify:

- $\quad$ Respecting faculty, staff, fellow students, guests, and all university property, policies, rules and regulations.

- $\quad$ Taking responsibility for one's choices and actions.

- $\quad$ Accepting the consequences of one's inappropriate choices and actions.

- $\quad$ Communicating in a professional and courteous manner in all forms, and at all times, whether verbal, nonverbal or written. 


\section{Design And Implementation Of Student Civility Brochure}

With the completion of the student civility code, the task force turned its efforts to the design and communication of a student civility guide. The task force agreed that three distinctive brochures were needed for the following groups: students, faculty, and staff. Task force members benchmarked several student civility brochures from various colleges and universities. Additionally, informal student surveys were also conducted to gain information and insights.

Based upon their interests and areas of expertise, task force members were divided into subgroups to design a working draft either for students, faculty, or staff. Several topics and questions were addressed by the subgroups ranging from "is the student civility code a legal contract? To "how should the brochures be distributed?" The diverse experiences and opinions of the committee members afforded an excellent opportunity for critique and debate when reviewing the drafts which proved to be invaluable in the design of the brochures. The final drafts were then submitted to the committee chairs whose responsibility was to analyze and verify that each brochure correlated with one another.

In regard to the student brochure, the committee agreed that this brochure was to be specific and detailed, in order to educate and inform the students. Furthermore, the recommended process for faculty to use was to be included in order to inform students the possible consequences. Also, a preamble was to be included to introduce the student civility code and the university's philosophy on teaching and learning. In order to simplify the student civility code and reduce expenses, a single sheet brochure was created (see Appendix). The committee also recommended that the brochure be distributed at all Freshmen Orientation sessions, and also distributed to various departments, faculty, and student organizations.

\section{CONCLUSION}

Student incivility continues to be a complex and growing issue at universities and colleges throughout the nation. Some major categories of student incivility consist of: disengaged, disinterested, disrespectful, disruptive, defiant, and disturbed behavior. Furthermore, student incivility may also contribute to faculty stress, discontent, and even burnout.

This paper has examined the design and creation of a student civility code that would foster a learning environment based upon mutual respect. The design of the brochure to communicate the student civility code was also discussed. At the time of this writing, the student civility code was brought forward to the Faculty Senate for approval; however, the document was tabled in order to give the Student Government Association (SGA) an opportunity to review and present it to the student body. In the fall semester, the resolution should again be taken up by the Faculty Senate.

\section{APPENDIX}

\section{Student Guide-Code Of Civility (Draft)}

Tips for Establishing \& Preserving a Civil Learning Community at Purdue University Calumet.

\section{Preamble}

Purdue University Calumet supports the principles of freedom of expression for both faculty and students. The University respects the rights of faculty to teach and students to learn. Maintenance of these rights requires classroom conditions that do not impede the learning process. Disruptive classroom behavior will not be tolerated. An individual engaging in such behavior may be subject to disciplinary action. To this end, Purdue University Calumet has adopted the Student Civility Code. 


\section{Purdue University Calumet Student Civility Code}

Purdue University Calumet places a priority on student learning. We value the inherent worth and dignity of every person, thereby fostering a community of mutual respect. We believe that in order to achieve these ideals, all Purdue University Calumet students are expected, while in the role as a student or representative of the university, to exhibit and practice civil behaviors that exemplify:

- $\quad$ Respecting faculty, staff, fellow students, guests, and all university property, policies, rules and regulations.

- $\quad$ Taking responsibility for one's choices and actions.

- $\quad$ Accepting the consequences of one's inappropriate choices and actions.

- $\quad$ Communicating in a professional and courteous manner in all forms, and at all times, whether verbal, nonverbal, or written.

\section{Student Rights}

Students have the right to a learning environment free of disruptive behaviors.

\section{Faculty Rights and Responsibilities}

Faculty has the right to define behavior expectations in the classroom and expect students to abide by them. Faculty has the responsibility to manager and address classroom disruption. Faculty has the right, and responsibility, to define expected classroom behavior to address disruptive student behavior.

\section{Staff Rights and Responsibilities}

Staff has the right and responsibility to define expected behaviors necessary to conduct any university activity free of disruption or obstruction.

\section{Student Expectations}

Students are expected and required to abide by the laws of the State of Indiana and of the United States and the rules and regulations of Purdue University, to conduct themselves in accordance with accepted standards of social behavior, to respect the rights of others, and to refrain from any conduct which tends to obstruct the work of the University. A student who violates these general standards of conduct may be subject to administrative actions as defined in the Regulations Governing Student Conduct, Disciplinary Proceedings and Appeals found on the Office of Student Services' webpage www.calumet.purdue.edu/stuserv or Student Handbook.

\section{Definitions}

- $\quad$ Faculty member shall include all persons authorized by Purdue University Calumet or any of its units to conduct instruction of students enrolled in the University's courses or programs.

- $\quad$ Classroom shall include any gathering of faculty member(s) and students for the purposes of teaching and learning authorized by Purdue University Calumet or any of its units.

- University activity means any teaching, research administrative, disciplinary function, proceedings, ceremony, or activity conducted by or under the authority of the University.

- $\quad$ University property means property owned, controlled, used or occupied by the University.

- $\quad$ Obstruction or Disruption of a University activity means unlawful or objectionable acts or conduct (1) which seriously threaten the ability of the University to maintain its facilities available for performance of its educational activities, (2) which are in violation of the reasonable rules and standards of the University designed to protect the academic community from unlawful conduct, or (3) which present a serious threat to person or property of the academic community.

- $\quad$ Staff shall include full-time and part time individuals who are part of the following employee groups: clerical/service employees as defined in Business Office Memorandum No. 66, administrative/professional 
employees as defined in Executive Memorandum No. B-55, and graduate administrative/professional employees.

\section{Recommended Step Approach in Handling Disruption in the Classroom}

It is recommended that an instructor use progressive approach, however, there are some behaviors that may require more immediate and severe action, including dismissing the class or calling the University Police. Instructor may go directly to step three if needed.

\section{$1^{\text {st }}$ Incident of Disruptive Behavior}

When a student engages in disruptive actions after instructor defined and explained appropriate classroom behavior, instructor will call the entire class to order and review the behavioral expectations again. Instructor will remind students that instructor's list is not exhaustive and no disruptive behavior will be tolerated. Instructor will refer students to their copy of the Regulations Governing Student Conduct, Disciplinary Proceedings and Appeals.

$2^{\text {nd }}$ Incident of Disruptive Behavior - Personal, Specific Warning

Instructor will ask the student for a conference (after class) to explain the specific disruptive behavior that the student is exhibiting. Instructor will very clearly tell student that they must stop the disruptive behavior immediately, or they will be subject to actions under Regulations Governing Student Conduct, Disciplinary Proceedings, and Appeals up to, and including, administrative withdrawal from class.

Instructor may put the warning in writing for the student, and give to him/her, and keep as part of student's files. If after receiving the warning, the student wants to discuss the issue, the student may schedule an appointment to speak with instructor.

$3^{\text {rd }}$ Incident of Disruptive Behavior - Action Taken

Instructor will petition for action to be taken to as follows:

- $\quad$ Administratively Withdraw student from class (must have sign off of Dept. Head/Dean)

- $\quad$ Administratively Withdraw student from class (must have sign off of Dept. Head/Dean and send to the Dean of Students Office for further sanctioning

- $\quad$ Change student to another section

- $\quad$ Other action as deemed necessary

\section{Examples of Troublesome/Disruptive Behavior in the Classroom}

Troublesome behavior in the classroom may be classified as anything that disrupts or disturbs your learning. Listed below are a few examples of troublesome behavior you may have experienced in your classroom:

\footnotetext{
- $\quad$ Cellular phones and beepers

- $\quad$ Eating or drinking in the classroom

- $\quad$ Excessive tardiness

- $\quad$ Leaving the lecture early

- $\quad$ Leaving the lecture and coming back with food and/or drink

- $\quad$ Making offensive remarks

- $\quad$ Missing deadlines

- $\quad$ Prolonged chattering

- $\quad$ Reading newspapers during class

- $\quad$ Sleeping
} 
- $\quad$ Talking out of turn

- $\quad$ Arriving late to class

- $\quad$ Dominating discussions

- $\quad$ Shuffling backpacks and notebooks nosily

- $\quad$ Overt inattentiveness

- $\quad$ Using profanity and offensive language

- $\quad$ Chewing or popping gum in class

- $\quad$ Constantly talking in class

- $\quad$ Coming to class high or inebriated

- $\quad$ Bringing children to class and they are disruptive

- $\quad$ Nosily packing up to go when class is not over

- $\quad$ Leaving during an exam and returning to class without permission

\section{Communication Tip}

If you experience any of the troublesome behaviors listed in this brochure, please feel free to contact your instructor, university policy, Dean of Students or other university administrators.

\section{REFERENCES}

1. American Council on Education and the Carnegies Foundation for the Advancement of Teaching (1990). Campus Life: In Search of Community. Washington, D.C.

2. Gonzalez, Virginia and Estela Lopez (April, 2001). The Age of Incivility. AAHE Bulletin.

3. Ivancevich, John, M. and Michael T. Matteson (2002). Organizational Behavior and Management. 6 Edition, Boston: McGraw-Hill Irwin.

4. Kauffman, James M. and Harold J. Burbach (February, 1998). Creating Classroom Civility. The Education Digest. Volume 63, Number 12. pp. 12-18.

5. Morrissette, Patrick J. (May, 2001). Reducing Incivility in the University/Classroom. International Electronic Journal For Leadership in Learning. Volume 5, Number 4. pp 2-11. 